Archives of Agriculture and Environmental Science

\title{
Key to Indian species of genus Brachygrammatella Girault (Hymenoptera: Trichogrammatidae) with re-description of $B$. indica and some new distributional records
}

\section{Mohd. Yousuf, Mohsin Ikram* (iD and Neha Rajwar}

Forest Entomology Discipline, Forest Protection Division, Forest Research Institute, P.O. New Forest, Dehradun - 248006 (Uttarakhand), INDIA

"Corresponding author's E-mail: mohsin3757@gmail.com

\section{ARTICLE HISTORY}

Received: 19 February 019

Revised received: 25 February 2019

Accepted: 03 March 2019

\section{Keywords}

Brachygrammatella

Indian species

Re-description records

Trichogrammatidae

\begin{abstract}
The aim of the study was to re-describe the egg parasitoid Brachygrammatella indica Viggiani and Hayat with some additional morphometric characters, especially of the genitalic component with SEM photography, they are mostly attacked on eggs of hemipterous insect pests and they keep their population under check and balance. During present research, materials were collected from the forestry and adjoining agro-forestry areas of Bihar, Haryana, Punjab, Uttarakhand and Uttar Pradesh by sweeping with net and parasitized eggs collection. In this paper Brachygrammatella indica Viggiani \& Hayat is re-described with some new distributional records and key to Indian species of genus Brachygrammatella Girault also updated.
\end{abstract}

(C)2019 Agriculture and Environmental Science Academy

Citation of this article: Yousuf, M., Ikram, M. and Rajwar, N. (2019). Key to Indian species of genus Brachygrammatella Girault (Hymenoptera: Trichogrammatidae) with re-description of $B$. indica and some new distributional records. Archives of Agriculture and Environmental Science, 4(1): 109-112, https://dx.doi.org/10.26832/24566632.2019.0401017

INTRODUCTION

Species of genus Brachygrammatella Girault are important egg parasitoids of hemipterous insect pest and they keep the population of insect pests under check and balance (Lotfalizadeh et al., 2016; Moravvej et al., 2016). It is represented by 9 species worldwide: B. coniclavata (Lin, 1993); B. hilli (Viggiani, 1968); B. indica (Viggiani and Hayat, 1974); B. jaipurensis (Yousuf and Shafee, 1988); B. nebulosi (Girault, 1915); B. perplexa (Girault, 1915); B. salutaris (Doutt, 1969); B. speciosissima (Girault, 1912) and $B$. ventralis (Doutt, 1969) of which two species, B. indica Viggiani \& Hayat and B. jaipurensis Yousuf and Shafee are recorded from India. Hayat (2008) synonymized B. aligarhensis Khan, B. longiclavata Khan and B. indica Khan with B. indica Viggiani \& Hayat. In this paper Brachygrammatella indica Viggiani \& Hayat (both $\delta^{\top} \&$ ) re-described with some additional characters. Key to Indian species of genus Brachygrammatella Girault is also updated with some new distributional records (Yousuf et al., 2015).

This short communication focused for lighting the keys to Indian species of genus Brachygrammatella Girault (Hymenoptera:
Trichogrammatidae) with re-description of $B$. indica and evaluation of some new distributional records.

\section{MATERIALS AND METHODS}

\section{Study design and sample processing}

The materials were collected from the forestry and adjoining agro-forestry areas of Bihar, Haryana, Punjab, Uttarakhand and Uttar Pradesh. Two methods were used during collection, sweeping and parasitized eggs collection. Sorted out specimens from collected samples and emerged parasitoids from eggs were preserved in $70 \%$ alcohol. Following the normal process of dehydration, specimens were dissected in clove oil under stereoscopic microscope for studying the important taxonomic characters; dissected body parts were kept in a drop of euparol on slides and covered with coverslips.

Apparatus and instruments

Only body lengths of specimens were measured in millimeters, all other measurements were taken from the divisions of a linear scale micrometer placed in the eye piece of a Nikon 
Digital Sight attached with Optiphot Microscope, at 10×, 20× and $40 \times$ for slide-mounted parts. Scales were placed on photographs of slide mounted parts and measurements were taken with the help of NIS-ELEMENT software in micrometer $(\mu \mathrm{m})$. Photographs of slide-mounted specimens were taken with digital camera "Nikon Digital Sight attached with Optiphot Microscope (Japan)" fitted over a compound microscope (Leica's Leitz Labor Lux S). For scanning electron microscopy (SEM), the specimens were dehydrated in ascending grades of ethanol and then subjected to critical point drying. These were then glued on stubs with double sided sticky tape and gold coated. The Scanning electron micrographs were taken by JSM. 6510LV-JOEL (Japan).

The following abbreviations are used: OOL = Ocello-ocellar length; POL= Post-ocellar length; $C 1 \& C 2=$ Club segments $1 \& 2$; $\mathrm{STV}=$ Stigmal vein; $M V=$ Marginal vein; $P M=$ Pre marginal vein .

\section{RESULTS AND DISCUSSION}

Key to Indian species of Brachygrammatella Girault based on females

\section{B. indica Viggiani \& Hayat}

Antennae with club about $2 \times$ as long as wide, pedicel less than $1.5 \times$ as long as wide, two anelli present, scape less than $3 \times$ as long as wide; marginal fringe absent (Figures 1-3).

\section{B. jaipurensis Yousuf \& Shafee}

Antennae with club less than $2 \times$ as long as wide, pedicel more than $1.5 \times$ as long as wide, single anellus, scape slightly more than $3 \times$ as long as wide; marginal fringe very short, less than $1 / 10^{\text {th }}$ of wing width.

\section{Brachygrammatella indica Viggiani \& Hayat}

Brachygrammatella (Pseudbrachygramma) indica Viggiani \& Hayat, 1974: 150. Brachygrammatella indica Khan, 1975a: 431. Synonymized by Hayat, 2008: 3.

Brachygrammatella aligarhensis Khan, 1976: 392. Synonymized by Hayat, 2008: 3.

Brachygrammatella longiclavata Khan, 1975b: 635. Synonymized by Hayat, 2008: 3.

\section{Re-description}

\section{Female}

Length $0.65 \mathrm{~mm}$ (Figure 1A). Head with fronto-vertex pale yellow; eyes and ocelli red; Mandibles golden yellow with tip brown. Antennae with scape and pedicel yellow except club brown in colour. Midlobe of mesoscutum yellow except dorsellum and propodeum parts with light bright yellow. Fore and hind wings hyaline except light infuscation beneath venation.

\section{Head}

(facial view) (Figure 3A) 1.12× as broad as long (260: 232). Ocelli arranged in equailateral triangle, OOL $2.8 \times$ as long as POL; eyes $3 \times$ as long as malar space; mandibles with tri-denticles (Figure 1D). Antennae (Figure 1B) with scape $2.84 \times$ as long as broad (74: 26); pedicel $1.32 \times$ as long as broad (45: 34); two anelli present; funicle about $2 \times$ wider than long; club two-segmented ( $C 1$ and C2), about $2 \times$ as long as broad (87: 41 ).

\section{Mesosoma}

(Figure 1E) Midlobe of mesoscutum about $1.36 \times$ wider than long (167: 123) with 2 pairs of short setae present on dorsal surface; midlobe of scutellum 1.61× wider than long (150: 93) with 2 pairs of setae, dosrsellum $0.53 \times$ as long as propodeum (16: 30). Fore wings (Figure 1F) with dens setae, about $2 \times$ as long as broad (559: 263), marginal fringe absent, MV broad with numerous stae, almost as long as PM, STV rudimentary.

\section{Metasoma}

(Figures 1E and 3D) Gaster longer than mesosoma; ovipositor short (Figure 2A), not extending upto apex of genitalia, about $0.90 \times$ as long as hind tibia.

\section{Male}

Similar to the female. Antenna (Figure $1 \mathrm{C}$ ) with scape about $4 \times$ as long as wide (78: 20 ), pedicel $1.33 \times$ as long as wide (44: 33), 2 anelli, funicles (F1 \& F2) 1.6× wider than long; club 2 segmented, $1.7 \times$ as long as wide.

\section{Genitalia}

(Figures 2B and 3E) Tubular in shape; about $0.70 \times$ shorter than hind tibia (115:165).

\section{Examinations in the Indian states}

\section{Haryana}

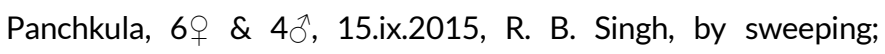
Mahendragarh, Faizabad, 1ㅇ, 14.vii.2018; Kukshi, 1§; Jhajjar, Babarpur, 1ㅇ, 17.vii.2018; Chandol, 1울 Dawla, 1; ex. eggs of Oxyrachis tarandus (Fabricius) on Prosopis juliflora. Faridabad, Pali Village, 1q, 29.v.2018, S. Khan, by sweeping; Nuh, Ghasera, 1, M. Ikram, ex. eggs of Oxyrachis tarandus (Fabricius) on Acacia sp.

Bihar

Kaimur, Passoiya, 1ㅇ, 18.vi.2018; Pateri, 1ㅇ, M. Ikram; Pusauli, 1 , M. Ikram, by sweeping.

Punjab

Taran Tarn, Muradnagar, 1언.11.ix.2013; M. Yousuf, by sweeping.

\section{Uttar Pradesh}

Mirzapur, Bokaria, 1q, 18.vi.2018; Saharanpur, Biharigarh, 21.viii.2018, 2ᄋ; Jhansi, Simra, 02.ix.2018; $1 \delta^{1} \&$ 2 ; Jhansi, Lokar, 1; A.K. Mishra, by sweeping; Varanasi, Parjanpur, 19 , 19.vi.2018; Bithalpur, 1q, 19.vi.2018; Gopipur, 19; Manorathpur, 1 , M. Ikram, by sweeping. 


\section{Uttarakhand}

Dehradun, New Forest, 19, 23.vii.2018, M. Ikram, by sweeping; 1우 31.vii.2018; M. Ikram. Ex. Eggs of Oxyrachis tarandus (Fabricius) on Prosopis juliflora and Acacia nilotica.

Habit and habitats

Host

Eggs of Oxyrachis tarandus (Fabricius) on Prosopis juliflora and

\section{Acacia sp.}

\section{Distribution}

INDIA: Maharashtra, Punjab, Tamilnadu, Uttar Pradesh, (Khan 1975a \& b).

\section{Present records}

Punjab (Tarn taran); Uttarakhand (Dehradun); Uttar Pradesh (Saharanpur, Jhansi, Varanasi); Haryana (Panchkula, Mahendragarh, Jhajjar, Faridabad, Nuh).
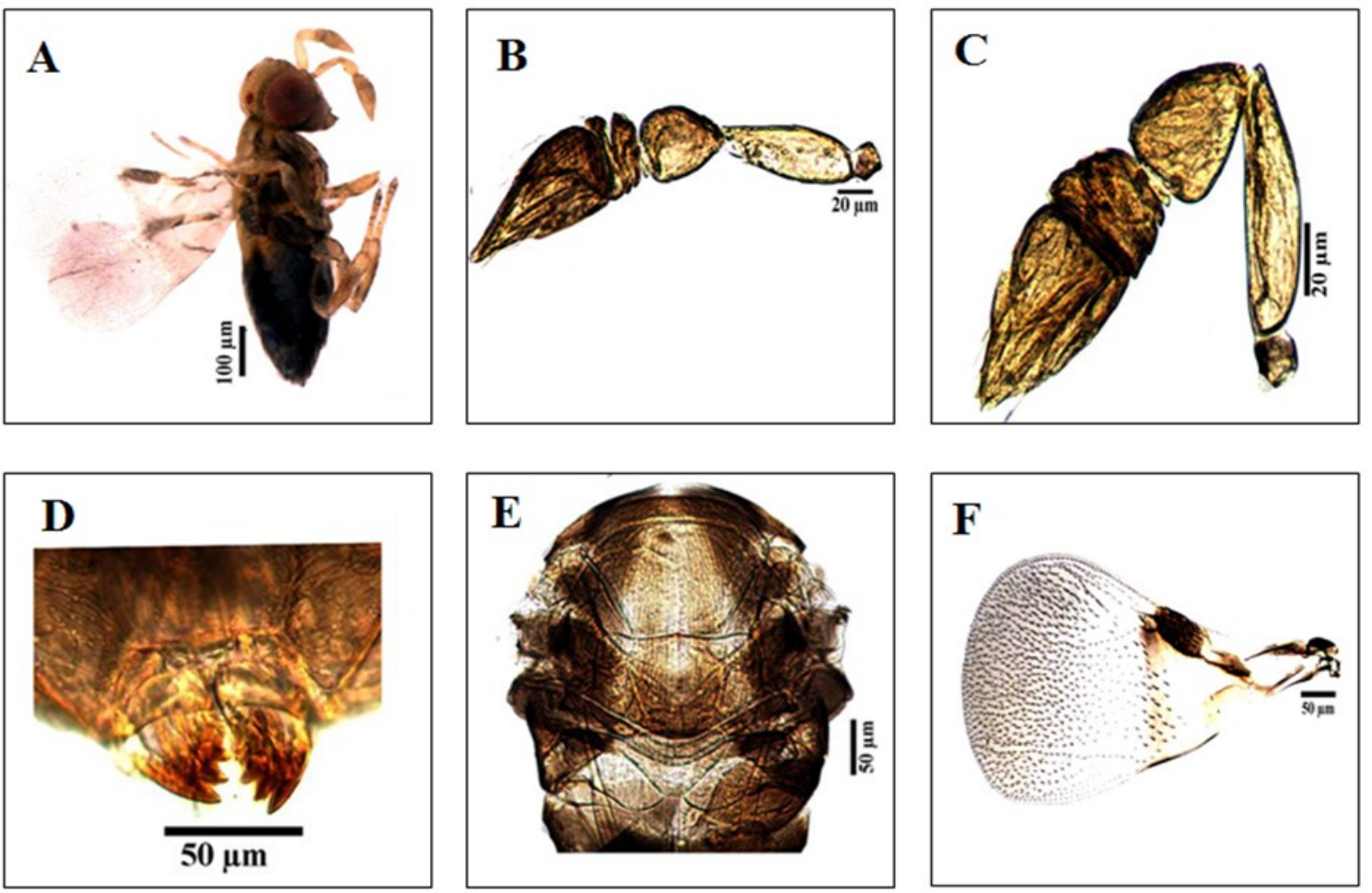

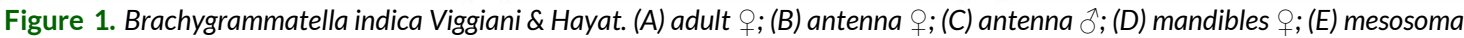
$\rightarrow$ and (F) forewing ${ }^{+}$.

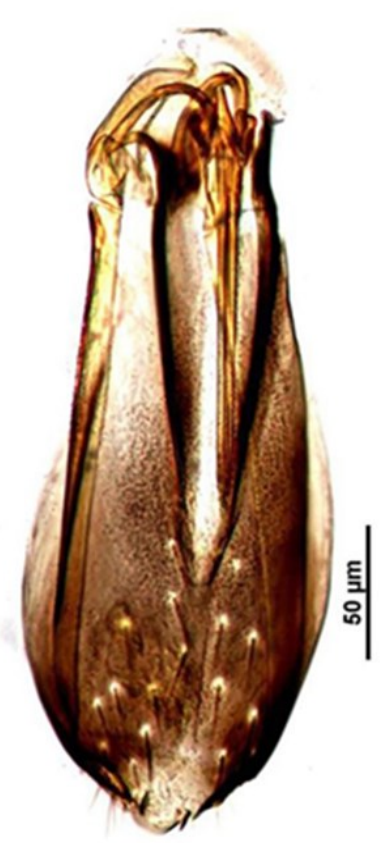

A

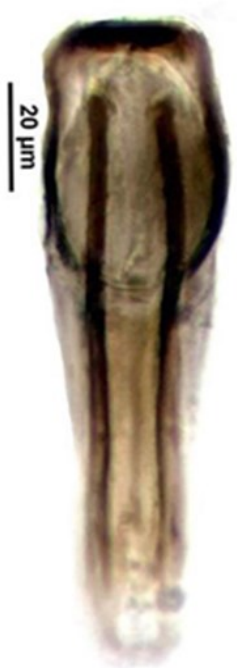

B
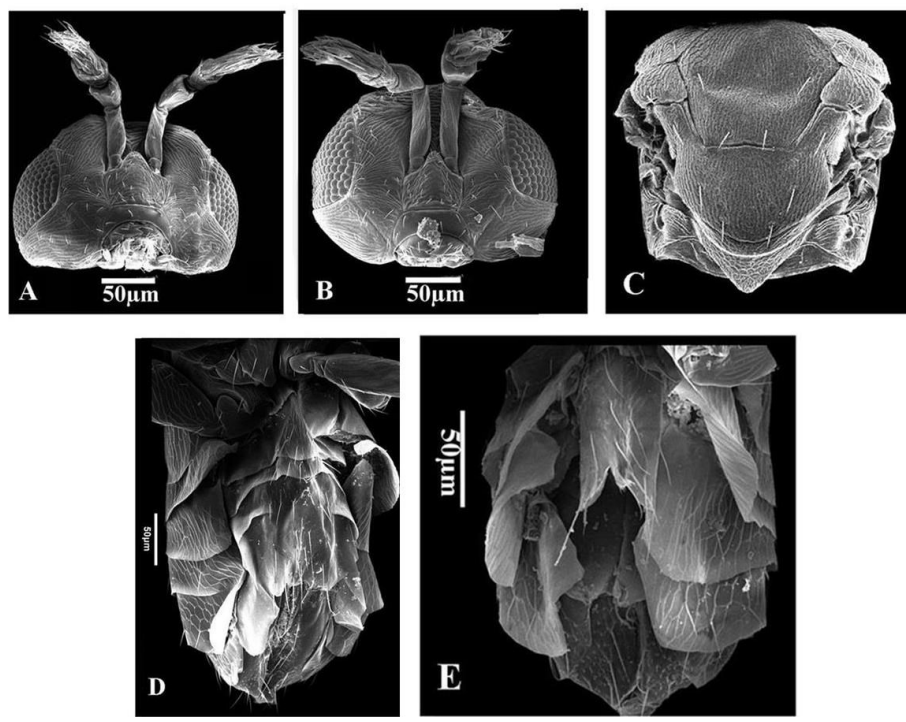

Figure 3. Brachygrammatella indica Viggiani \& Hayat. (A) head and antenna + ; (B) head and antenna ${ }^{\circ}$; (C) mesosoma ${ }_{+}$; (D) metasoma ${ }_{+}$and (E) metasoma ô.

Figure 2. Brachygrammatella indica Viggiani \& Hayat. (A) Genitalia 9 and (B) Genitalia ô. $^{2}$. 
Conclusion

Brachygrammatella indica was described by Viggiani \& Hayat, based on female, later (Hayat, 2008) synonymized B. aligarhensis Khan, B. longiclavata Khan and B. indica Khan with B. indica Viggiani \& Hayat. Earlier worker described it poorly, so authors have re-described with some additional morphometric characters and provided SEM (Scanning electron micrograph) images, which will be helpful for further identification.

\section{ACKNOWLEDGEMENT}

The authors are greatly indebted to the Director, Forest Research Institute, Dehradun for providing necessary research facilities.

Open Access: This is an open access article distributed under the terms of the Creative Commons Attribution 4.0 License, which permits unrestricted use, distribution, and reproduction in any medium, provided the original author(s) if the sources are credited.

\section{REFERENCES}

Doutt, R.L. (1969). The genus Brachygrammatella Girault (Hymenoptera: Trichogrammatidae). Pan-Pacific Entomologist, 44(4): 289-294.

Girault, A.A. (1912). Australian Hymenoptera Chalcidoidea. I. The family Trichogrammatidae with description of new genera and species. Memoirs of the Queensland Museum, 1: 66-116.

Girault, A.A. (1915). Australian hymenoptera chalcidoidea. I. Second Supplement. Mem. Queensl. Mus, 3: 142-153.

Hayat, M. (2008). Taxonomic notes on the Indian Trichogrammatidae (Hymenoptera: Chalcidoidea), with redescriptions and records of some species. Oriental Insects, 42: 1-32.
Khan, M.Y. (1975a). A new species of the genus Brachygrammatella Girault (Hymenoptera: Trichogrammatidae) from Aligarh, India. Current Science, 44(12): 430-433.

Khan, M.Y. (1975b). A new species of Trichogrammatidae (Hymenoptera) reared from the eggs of Oxyrachis tarandus Fabr. (Hymenoptera; Membracidae), Current Science 44: 635-636

Khan, M.Y. (1976), A new name for Brachygrammatella indica Khan (Hymenoptera: Trichogrammatidae). Current Science, 45(10): 392.

Lin, N. Q. (1993). Four new species of Trichogrammatidae from China (Hymenoptera: Chalcidoidea). Acta Entomologica Sinica, 36(2): 211-212

Lotfalizadeh, H., Bayegan, Z.A. and Zargaran, M.R. (2016). Species diversity of Chalcidoidea (Hymenoptera) in the rice fields of Iran. Journal of the Entomological Research Society, 18(1): 99-111.

Moravvej, S.A., Shishehbor, P. and Lotfalizadeh, H. (2016). A checklist of Chalcidoidea (Insecta: Hymenoptera) of Khuzestan in southwestern Iran. Journal of Insect Biodiversity and Systematics, 2(1): 121-142.

Viggiani, G. (1968). Studies on Hymenoptera Chalcidoidea. XVII. New species of Trichogrammatidae. Bollettino del Laboratorio di Entomologia Agraria 'Filippo Silvestri', Portici, 26: 251-256.

Viggiani, G. and Hayat, M. (1974). New trichogrammatids from India (Hymenoptera Chalcidoidea). Bollettino del Laboratorio di Entomologia Agraria 'Filippo Silvestri', Portici, 31:150-151.

Yousuf, M. and Shafee S.A. (1988). Taxonomy of Indian Trichogrammatidae (Hymenoptera: Chalcidoidea). Indian Journal of systematic Entomology, 4(2): 55-200.

Yousuf, M., Ikram, M. and Faisal, M. (2015). Current status of Indian Trichogramma spp. along with their distributional record and host range. Indian Forester, 141(7): 806-812. 